\title{
Early rise in 'pitted' red cell count as a guide to susceptibility to infection in childhood sickle cell anaemia
}

\author{
D W ROGERS, BERYL E SERJEANT, AND G R SERJEANT
}

Medical Research Council Laboratories, University of the West Indies, Kingston, Jamaica

SUMMARY 'Pitted' red cell counts (pit counts) were performed serially during a period of 18 months in 130 Jamaican children with homozygous sickle cell (SS) disease aged $0-4$ years. Raised pit counts, defined as $10 \%$ or more 'pitted' red cells, were present in $23 \%$ of the children at age 12 months, in $42 \%$ at age 24 months, and in $52 \%$ at age 36 months. Radioactive colloid spleen scans showed no splenic uptake in 11 children with palpable spleens and raised pit counts. Eight episodes of severe bacterial infection occurred in 7 children, all of whom had raised pit counts before $(n=6)$ or at the time of infection $(n=1)$. Of the 52 children with pit counts followed from age 12 months or younger, all 4 who developed severe infections had raised pit counts at or before age 12 months Pit counts are a guide to susceptibility to severe infections in SS children. Children whose pit counts rise before age 12 months are at greater risk of subsequent infection; this may be related to loss of splenic function before first encounter with the infecting organism.

Susceptibility to severe bacterial infections, especially pneumococcal septicaemia and meningitis, is a serious complication of homozygous sickle cell (SS) disease in childhood, ${ }^{1}$ and contributes to the high early mortality. ${ }^{2}$ Similar susceptibility is seen in asplenic children, ${ }^{3}$ and in children who undergo splenectomy in whom the risk of subsequent infection is greater the younger they are when the spleen is removed. ${ }^{4}$ Susceptibility to these infections in SS children has been ascribed to functional asplenia, impairment of splenic reticuloendothelial function while the spleen is still enlarged, which is an acquired defect demonstrable by radioactive colloid spleen scans, ${ }^{5}$ and by failure of the normal antibody response to intravenous antigen. ${ }^{6}$

Counts of so called 'pitted' red cells (pit counts), estimated using differential interference contrast microscopical examination (Fig. 1), have also been used as a measure of splenic reticuloendothelial function, the proportion of 'pitted' red cells increasing in the absence of a functioning spleen. ${ }^{7-9}$ The description 'pitted' is a misnomer, electron microscope studies suggesting that the 'pits' are vesicles underlying the red cell membrane. As pit counts can be performed quickly and easily on one drop of blood they are particularly"suitable for serial studies of splenic function in SS children. ${ }^{10} 11$

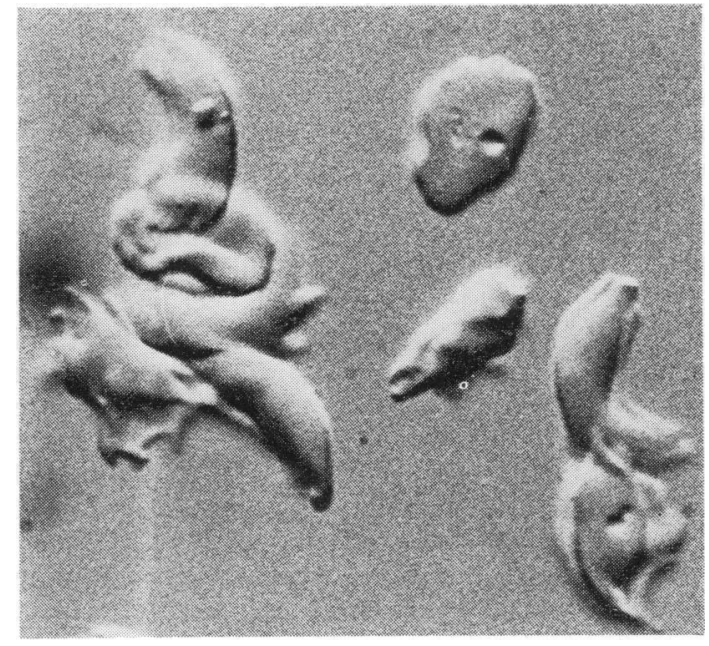

Fig. 1 'Pitted' red cells in sickle cell disease. $\times 2500$.

\section{Patients and methods}

Pit counts were estimated serially from November $\stackrel{2}{2}$ 1976 to July 1978 in 130 SS children aged 0-4 years 
who had been diagnosed in the cord blood screening programme at Victoria Jubilee Hospital, Kingston, Jamaica and followed up in a special clinic at the University Hospital of the West Indies as part of the Medical Research Council's study of the natural history of sickle cell disease. Criteria for the diagnosis of SS disease have been previously described. ${ }^{2}$ Pit counts were also estimated for 139 Jamaican children with normal haemoglobin genotype AA aged 1-4 years who were being followed up at the clinic as controls, and for 16 SS children and adults who had undergone splenectomy.

Specimens were taken at routine blood tests performed at 3-monthly intervals (6 monthly for AA children) or when clinically indicated. Blood was taken by finger prick, except for yearly venepunctures or if venepunctures were required for blood cultures or biochemical or serological investigations. One drop of fresh blood was mixed with $0.5 \mathrm{ml} 5 \%$ formol saline in a stoppered tube and stored at $4{ }^{\circ} \mathrm{C}$, the cells settling to the bottom of the tube. Specimens were stored for periods ranging from 4 hours to 8 weeks.

For counting, the cells were resuspended by shaking the tube and a small drop of the suspension was placed on a microscope slide, covered with a coverslip, and viewed under a $\times 100$ oil immersion lens. Pit counts were estimated by counting 500 red cells using differential interference microscopy (Nomarski optics) on a standard Zeiss microscope. The pit count was defined as the percentage of red blood cells appearing to have at least one circular indentation, regardless of the size or the number of indentations. Consistency between observers and between estimations on the same specimen before and after several months' storage was checked, the counts falling within a range of \pm 2.5 for each specimen.

Radioactive $\left({ }^{99 \mathrm{~m}} \mathrm{Tc}\right)$ colloid spleen scans were performed on 14 SS children in whom confirmation of impaired splenic function was indicated, the most common indication being before splenectomy for acute splenic sequestration.

Severe infections were defined as isolation of a pathogenic organism from blood or cerebrospinal fluid or at necropsy, or purulent meningitis without isolation of an organism. Infections were diagnosed in the clinic, during hospital admissions, and by routine culture at necropsy if performed. For children in whom pit counts had been performed from age 1 year or younger survival curves for time to first severe infection were calculated for two groups. Group 1 comprised children whose pit counts rose to $10 \%$ or greater before or at age 12 months, group 2 comprised children whose pit counts had not risen above $9 \%$ before age 13 months.

\section{Results}

Pit counts were below $2 \%$ in $118(85 \%)$ of 139 and below $5 \%$ in $132(95 \%)$ of 139 AA children aged 1-4 years. The remaining 7 control children with counts of 5 to $8 \%$ included children with identifiable illnesses-such as pharyngitis, skin sepsis, or scabies. Repeat counts in 3 of these children showed subsequent falls in pit counts from 8 to $3 \%, 8$ to $1 \%$, and 5 to $0 \%$.

Pit counts from serial studies in 130 SS children have been combined (Fig. 2) to show the distributions of pit counts with age. Ranges, medians, and quartiles are shown, as until about age 4 years the distributions are skewed towards zero. Raised pit counts, defined as $10 \%$ or more 'pitted' red cells, occurred in $23 \%$ SS children at age 1 year, in $42 \%$ at age 2 years, and in $52 \%$ at age 3 years. Median pit counts showed a progressive increase reaching $17.5 \%$ at age 51 months compared with a median of $18.1 \%$ in 16 post-splenectomy patients.

Radioactive colloid spleen scans showed no splenic uptake in $11 \mathrm{SS}$ children with palpable spleens and pit counts ranging from 9 to $18 \%$, and in 2 SS children who had never had palpable spleens, one of whom had a pit count of $25 \%$ and the other a normal pit count. Splenic colloid uptake was demonstrated in 1 child with a palpable spleen and a pit count of $3 \%$.

Pit counts in relation to 8 episodes of severe infection in $7 \mathrm{SS}$ children (Table 1) indicate that pit counts were raised before the episode in 6 children and at the episode in 1 child. The relationship

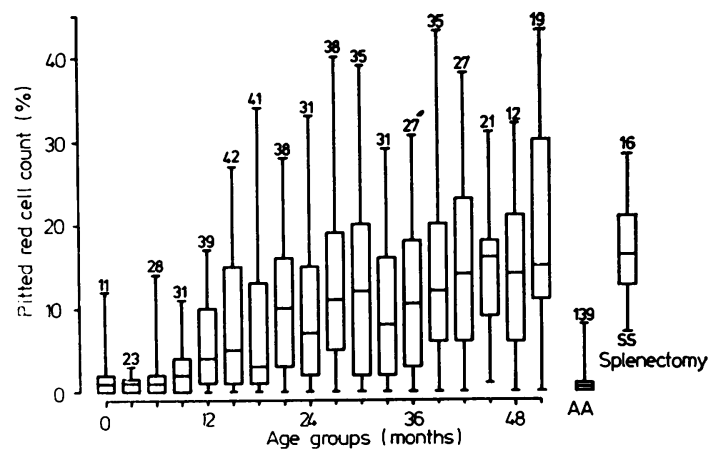

Fig. 2 Distribution of pit counts (median, quartiles, and range) according to age in 130 children with $S S$ disease age 0-51 months followed for up to 18 months. $A A$ refers to 139 controls with normal haemoglobin age 1-4 years. SS splenectomy refers to 16 adults and children in whom splenectomy had previously been performed. Numbers refer to observations in each age group. 
Table 1 Pit counts and severe bacterial infections

\begin{tabular}{|c|c|c|c|c|c|c|c|c|c|c|}
\hline \multirow[t]{2}{*}{ Case } & \multicolumn{3}{|c|}{ Age (months) } & \multirow[t]{2}{*}{ Infection } & \multirow[t]{2}{*}{ Organism } & \multirow[t]{2}{*}{ Outcome } & \multirow{2}{*}{$\begin{array}{l}\text { Previous } \\
\text { pit count } \\
(\%)\end{array}$} & \multirow{2}{*}{$\begin{array}{l}\text { Pit count } \\
\text { at infection } \\
(\%)\end{array}$} & \multirow{2}{*}{$\begin{array}{l}\text { Subsequent } \\
\text { pit count } \\
(\%)\end{array}$} & \multirow{2}{*}{$\begin{array}{l}\text { Previous } \\
\text { infections }\end{array}$} \\
\hline & $\begin{array}{l}\text { Spleen } \\
\text { first felt }\end{array}$ & $\begin{array}{l}\text { Pit count } \\
\text { raised }\end{array}$ & $\begin{array}{l}\text { At } \\
\text { infection }\end{array}$ & & & & & & & \\
\hline 1 & 6 & 9 & 9 & Septicaemia & S. pneumoniae & Survived & 4 & 13 & 15 & \\
\hline 2 & 8 & 10 & 14 & Osteomyelitis & S. californiae & Survived & 14 & Not known & 11 & \\
\hline 3 & 4 & & 16 & Septicaemia & S. pneumoniae & Survived & 16 & Not known & 34 & \\
\hline 4 & 3 & $\gtrless 12$ & 16 & Meningitis & $\begin{array}{l}\text { S. pneumoniae } \\
\text { S. typhimurium }\end{array}$ & Died & 18 & Not known & - & \\
\hline 5 & 2 & $<21$ & 21 & Septicaemia & $S$. pneumoniae & Died & 24 & Not known & - & $\begin{array}{l}H . \text { influenzae } \\
\text { septicaemia } \\
\text { (at } 19 \text { months) }\end{array}$ \\
\hline \multirow{3}{*}{$\begin{array}{l}6 \\
7\end{array}$} & 6 & $\gtrless 19$ & 30 & Septicaemia & S. aberdeen & Survived & 24 & 24 & 14 & \\
\hline & 6 & $\gtrless 36$ & 42 & Meningitis & S. pneumoniae & Survived & 12 & 23 & 15 & $\begin{array}{l}\text { S. pneumoniae } \\
\text { meningitis (at } \\
29 \text { months) }\end{array}$ \\
\hline & & & 57 & Meningitis & S. pneumoniae & Survived & 21 & 12 & 10 & $\begin{array}{l}H . \text { influenzae } \\
\text { osteomyelitis } \\
\text { (at } 32 \text { months) }\end{array}$ \\
\hline
\end{tabular}
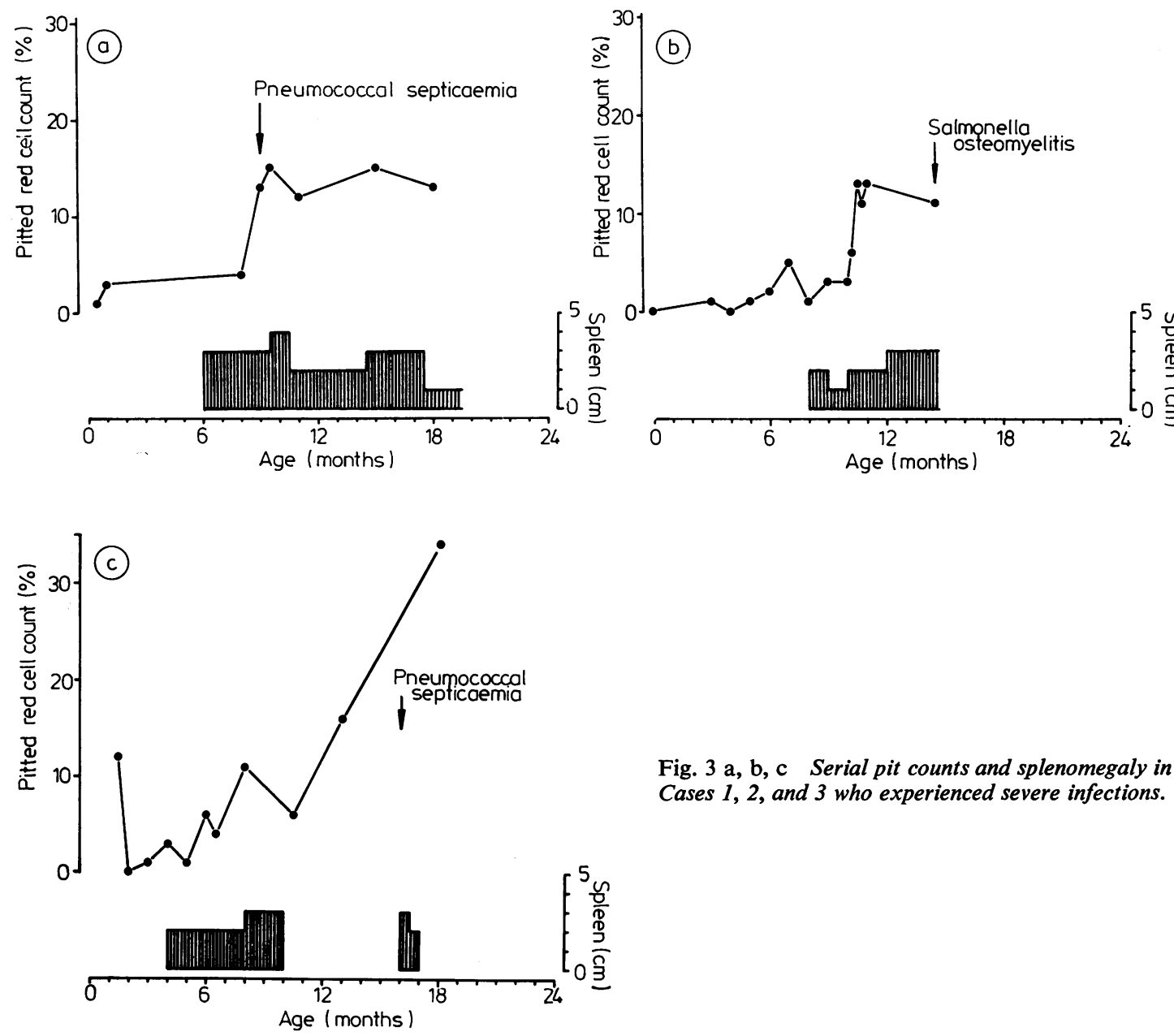

Fig. 3 a, b, c Serial pit counts and splenomegaly in Cases 1, 2, and 3 who experienced severe infections. 
Table 2 First severe infection according to pit count group

\begin{tabular}{llllll}
\hline Group & $\begin{array}{l}\text { Age when pit } \\
\text { count first raised }\end{array}$ & $\begin{array}{l}\text { No of } \\
\text { children }\end{array}$ & $\begin{array}{l}\text { Observed } \\
\text { infections }\end{array}$ & $\begin{array}{l}\text { Expected } \\
\text { infections }\end{array}$ & $\begin{array}{l}\text { Observed/ } \\
\text { expected }\end{array}$ \\
\hline 1 & $\begin{array}{l}\text { < } 12 \text { months } \\
\text { 12 months or }\end{array}$ & 17 & 4 & $1 \cdot 16$ & 3.45 \\
2 & not at all & 35 & 0 & 2.84 & 0 \\
\hline
\end{tabular}

*Expected number of first infections calculated by log-rank test.

between splenomegaly, rise in pit count, and subsequent severe infection in 3 patients is shown in Fig. 3a, b, and c.

In the 52 children whose pit counts had been estimated from age 12 months or earlier, all 4 who experienced severe infections had raised pit counts at or before age 12 months. Time to first severe infection (Table 2) for SS children was significantly related to raised pit counts at or before age 12 months by the log-rank test $\left(\chi^{2}\right.$ test, $\left.P<0 \cdot 01\right)$.

\section{Discussion}

Pit counts in AA children aged 1-4 years in the present study (mean $\pm 1 \mathrm{SD}, 0.73 \pm 1.54 \%$; range $0-8 \%$ ) were of the same order as those reported for normal adults by Holroyde and Gardner ${ }^{7}$ (2.6 $\pm 1 \cdot 1 \%$, range not quoted) and for normal subjects aged 2 months to 43 years by Casper et al. ${ }^{8}(0.5$ $\pm 0.5 \%$; range $0-2.6 \%$ ) but were higher than those reported by Pearson et al. ${ }^{9}$ for 35 normal children aged 6 months to 20 years $(0.08 \pm 0.003 \%$; range $0-0.8 \%$ ). Infections may explain some of the fairly high pit counts seen in AA children in this study.

A raised pit count was arbitrarily defined as a pit count of at least $10 \%$ for the following reasons. All AA children had pit counts below this level. Spleen scans in SS children with palpable spleens showed no splenic uptake of colloid at pit counts of $9 \%$ or greater, while the spleen scan of an SS child with a pit count of $3 \%$ showed uptake. Pearson et al. ${ }^{9}$ found pit counts of $12 \%$ or greater in children who had undergone splenectomy and in whom regeneration of splenic tissue was not suspected or demonstrated.

A child in whom the spleen had never been felt had a normal pit count, but unexpectedly no splenic activity detected on spleen scan, perhaps because of an ectopic spleen or compensatory activity in the remainder of the reticuloendothelial system.

All the severe infections in the present study occurred in children with raised pit counts. Serial pit counts from age 12 months or younger suggest that SS children whose pit counts rise at or before age 12 months are those at greater risk of subsequent infection.
A possible explanation for these findings is as follows. Individuals without functioning spleens are unable to mount an antibody response to intravenous antigen. ${ }^{612}$ In the experimental animal rapid clearance of pneumococci from the circulation by the liver is dependent on the presence of circulating antibody. ${ }^{13}$ Thus if splenic function is lost before first encounter with an invading organism, failure of the spleen-dependent antibody response may result in failure of clearance of the organism from the circulation by the liver. However if antibody already exists as a result of a previous encounter with the organism, or as a result of active or passive immunisation, the organism can be rapidly cleared from the circulation by the liver even in the absence of a functioning spleen. Thus the younger splenic function is lost the smaller the probability of previous encounter with an invading organism and consequent formation of circulating antibody, and so the greater the risk of subsequent septicaemia.

The ease and speed with which a pit count can be performed make this investigation suitable for clinic or ward use as an assessment of splenic assessment of splenic function. A normal pit count in an SS child at a particular time makes a severe bacterial infection on that occasion unlikely. Mortality from severe infections in sickle cell anaemia is highest in the first 2 years of life when fewer than $40 \%$ SS children have raised pit counts, and pit counts are therefore especially valuable in young children. Serial pit counts in SS children followed since birth establish the age of onset of functional asplenia and the subsequent risk of severe bacterial infection. Those at risk may benefit from prophylaxis, and a controlled trial comparing vaccination and penicillin prophylaxis is in progress.

We thank the staff of the Departments of Child Health, Microbiology, and Nuclear Medicine, University Hospital of the West Indies, the Bustamante Children's Hospital, the Medical Research Council Laboratories, and Victoria Jubilee Hospital, Kingston, Jamaica, for assistance.

\section{References}

1 Robinson M G, Watson R J. Pneumococcal meningitis in sickle-cell anemia. $N$ Engl J Med 1966; 274: 1006-8.

2 Rogers D W, Clarke J M, Cupidore L, Ramlal A M, Sparke B R, Serjeant G R. Early deaths in Jamaican children with sickle cell disease. $B r$ Med J 1978; i: 1515-6.

3 Waldman J D, Rosenthal A, Smith A L, Shurin S, Nadas A S. Sepsis and congenital asplenia. J Pediatr 1977; 90: 555-9.

4 Eraklis A J, Filler R M. Splenectomy in childhood: a review of 1413 cases. J Pediatr Surg 1972; 7: 382-8.

5 Pearson H A, Spencer R P, Cornelius E A. Functional asplenia in sickle cell anemia. $N$ Engl J Med 1969; 281 : 923-6. 
- Schwartz A D, Pearson H A. Impaired antibody response to intravenous immunization in sickle cell anemia. Pediatr Res 1972; 6: 145-9.

7 Holroyde C P, Gardner F H. Acquisition of autophagic vacuoles by human erythrocytes. Physiological role of the spleen. Blood 1970; 36: 566-75.

8 Casper J T, Koethe S, Rodey G E, Thatcher L G. A new method for studying splenic reticulo-endothelial dysfunction in sickle cell disease patients and its clinical application: a brief report. Blood 1976; 47: 183-8.

- Pearson H A, Johnston D, Smith K A, Touloukian R J. The born again spleen: return of splenic function after splenectomy for trauma. $N$ Engl J Med 1978; 298: 1389-92.

10 Pearson H A, McIntosh S, Ritchey A K, Lobel J S, Rooks Y, Johnston D. Developmental aspects of splenic function in sickle cell diseases. Blood 1979 ; 53: 358-65.
11 Sills R H, Oski F A. RBC surface pits in sickle hemoglobinopathies. Am J Dis Child 1979; 133: 526-7.

12 Rowley D A. The formation of circulating antibody in the splenectomized human being following intravenous injection of heterologous erythrocytes. J Immunol 1950; 64: 515-21.

13 Schulkind M L, Ellis E F, Smith R T. Effect of antibody upon clearance of $\mathrm{I}^{125}$-labelled pneumococci by the spleen and liver. Pediatr Res 1967; 1: 178-84.

Correspondence to $\mathrm{Dr} G \mathbf{R}$ Serjeant, Medical Research Council Laboratories (Jamaica), University of the West Indies, Kingston 7, Jamaica, West Indies.

Received 25 August 1981 